\title{
PENERAPAN PROJECT BASED LEARNING MODEL UNTUK MENINGKATKAN SIKAP ILMIAH MAHASISWA DALAM RANGKA MENGHADAPI ERA MERDEKA BELAJAR
}

\author{
Andik Purwanto*, Desy Hanisa Putri, Dedy Hamdani
}

Program Studi Pendidikan Fisika FKIP Universitas Bengkulu

Jl. WR. Supratman, Kandang Limun, Bengkulu

e-mail*: andik.purwanto@munib.ac.id

\begin{tabular}{c|c|c|c}
\hline Diterima 20 November 2020 & Direvisi 31 Maret 2021 & Disetujui 21 April 2021 & Dipublikasikan 30 April 2021 \\
\hline \multicolumn{4}{c}{ https://doi.org/10.33369/jkf.4.1.25-34 } \\
\hline
\end{tabular}

\begin{abstract}
ABSTRAK
Termodinamika merupakan salah satu cabang ilmu fisika yang mempelajari fenomena atau gejala alam yang terjadi di kehidupan sehari-hari, khususnya tentang panas dan perpindahannya. Pembelajaran matakuliah Termodinamika sering kali menimbulkan permasalahan karena tidak tepatnya dalam pemilihan model pembelajaran, sehingga kurang mampu mengoptimalkan proses pembelajaran yang pada akhirnya akan menyebabkan pengembangan sikap ilmiah mahasiswa kurang optimal. Pengembangan sikap ilmiah sangat diperlukan dalam rangka menghadapi era merdeka belajar, dengan adanya sikap ilmiah yang tepat maka mahasiswa dapat lebih mengembangkan keterampilan hidupnya (soft skill). Sikap ilmiah selalu dipengaruhi banyak faktor, salah satu faktor yang mempengaruhi ialah pemilihan model pembelajaran. Dalam penggunaan model pembelajaran seorang dosen dapat memilih model pembelajaran yang inovatif, yang mana akan membantu dosen dan mahasiswa dalam meningkatkan sikap ilmiahnya. Salah satu model pembelajaran yang bisa membuat mahasiswa kritis dalam proses pembelajaran adalah dengan menggunakan Project Based Learning Model. Penelitian ini bertujuan untuk meningkatkan sikap ilmiah dan hasil belajar mahasiswa Prodi Pendidikan Fisika FKIPUNIB pada mata kuliah Termodinamika melalui penerapan Project Based Learning Model. Penelitian dilakukan dengan penelitian tindakan kelas (PTK) yang dilakukan dalam beberapa siklus. Subjek dalam penelitian ini adalah seluruh mahasiswa Prodi Pendidikan Fisika FKIP-UNIB semester 3 Tahun Akademik 2020/2021. Instrumen yang digunakan lembar tes untuk mengukur hasil belajar dan angket sikap ilmiah. Analisis data dilakukan dengan statistik deskriptif. Hasil analisis data menunjukkan bahwa penerapan model Project Based Learning pada Matakuliah Termodinamika bagi mahasiswa semester 3 Prodi Pendidikan Fisika FKIP Universitas Bengkulu terjadi peningkatan pada sikap ilmiah dan hasil belajarnya.
\end{abstract}

Kata kunci: Project Based Learning Model, merdeka belajar, sikap ilmiah

\begin{abstract}
Thermodynamics is a branch of physics that studies natural phenomena or phenomena that occur in everyday life, especially regarding heat and its transfer. Thermodynamics subject learning often creates problems because it is not precise in choosing a learning model, so it is not able to optimize the learning process which in turn will cause the development of students' scientific attitudes to be less than optimal. The development of a scientific attitude is needed in order to face the era of independent learning, with the right scientific attitude, students can further develop their life skills (soft skills). The scientific attitude is always influenced by many factors, one of the factors that influence is the selection of a learning model. In using the learning model, a lecturer can choose an innovative learning model, which will help lecturers and students to improve their scientific attitude. One learning model that can make students critical in the learning process is to use the Project Based Learning Model. This study aims to improve the scientific attitude and learning outcomes of Physics Education Study Program students, FKIP-UNIB in the Thermodynamics course through the application of the Project Based Learning Model. The research was conducted with classroom action research (PTK) which was carried out in several cycles. The subjects in this study were all students of the Physics Education Study Program FKIP-UNIB semester 3 of the 2020/2021 Academic Year. The instrument used was the test sheet to measure learning outcomes and a scientific attitude questionnaire. Data analysis was performed using descriptive statistics. The results of data analysis showed that the implementation of the Project Based Learning model in the Thermodynamics Subject for 3rd semester students of the Physics Education Study Program, FKIP, Bengkulu University, has an increase in scientific attitudes and learning outcomes.
\end{abstract}




\section{PENDAHULUAN}

Mata kuliah Termodinamika adalah salah satu mata kuliah wajib yang disajikan dan diajarkan di PS Pendidikan Fisika JPMIPA FKIP UNIB, dan harus dikuasai seluruh mahasiswa di PS tersebut. Mata kuliah Termodinamika di PS Pendidikan Fisika JPMIPA UNIB mempunyai beban sebesar 3 SKS kegiatan perkuliahan tanpa praktikum (3-0 SKS) dan diberikan pada semester III. Pada mata kuliah Termodinamika tujuan pembelajaran adalah agar mahasiswa menguasai kompetensi profesional bidang fisika dengan beberapa indikator kompetensi. Mata kuliah ini memberikan pengatahuan tentang suhu dan kalor, sistem termodinamika, teori kinetik gas, persamaan keadaan, turunan parsial dalam termodinamika, hukum pertama termodinamika, penerapan hukum pertama termodinamika, entrophi, transformasi Legendre, energi bebas dan entalphi, Teori kinetik gas ideal, tekanan, kerja, dan potensial kimia , Relasi maxwell, ruang fase, statistik molekul-molekul (bose-eisntein, fermi-dirac, maxwell-boltzmann), fungsi distribusi, definisi entropi secara statistic, teori ensemble dan ensemble microkanonis, ensemble kanonis.

Berdasarkan hasil penelitian terdahulu pada matakuliah ini, ditemukan beberapa permasalahan dalam proses belajar mengajar. Beberapa permasalahan yang teridentifikasi antara lain : (1) Mahasiswa sulit untuk menyelesaikan persoalan atau permasalahan yang menyangkut pemahaman dalam menganalisis suatu masalah karena banyak dari mahasiswa yang lemah dalam penguasaan dari konsep konsep dasar fisika, hal ini terlihat dari hasil ujian baik dari UTS dan UAS mahasiswa. (2) Kemampuan mahasiswa dalam menjawab pertanyaan-pertanyaan yang diajukan dosen dalam perkuliahan juga masih rendah, hal ini terlihat hanya beberapa orang mahasiswa saja yang aktif untuk menjawab pertanyaan yang diajukan. (3) Mahasiswa tidak mampu mengkaitkan suatu konsep fisika tertentu dengan konsep fisika yang lain dan juga dalam menjelaskan fenomena alam dari konsep fisika yang di pelajari di kelas. (4) Mahasiswa tidak mampu menumbuhkan sikap ilmiah dalam menjelaskan fenomena alam yang menyangkut permasalahan termodinamika, sehingga mahasiswa merasa kurang bersemangat dalam menjalani perkuliahan termodinamika.

Berdasarkan masalah yang berhasil diidentifikasi, peneliti memperkirakan tentang penyebab timbulnya permasalahan tersebut adalah (1) Metode mengajar yang digunakan dosen selama ini kurang bervariasi (didominasi dengan Metode ceramah), sehingga aktivitas belajar-mengajar masih terpusat hanya pada dosen (teacher center) yaitu hanya memberikan informasi berupa teori, generalisasi, hukum dalil, rumus serta bukti bukti yang mendukung dan mahasiswa hanya menerima saja informasi yang diberikan dosen atau berkedudukan sebagai objek pembelajaran yang bersifat pasif. Pada metode pembelajaran ini yang terjadi hanya berupa transfert knowledge dan terbukti tidak memberikan hasil belajar mahasiswa yang optimal dan juga tidak memberikan dorongan untuk bersifat kreatif dan kritis pada mahasiswa. (2) Sebagian besar mahasiswa menganggap bahwa matakuliah Termodinamika merupakan matakuliah yang "berat", membosankan, hanya berisi rumus, hukum, dalil dan teori yang abstrak, serta kurang terkait dengan dunia nyata yang ada dalam kehidupan sehari-hari sehingga mereka hanya terfokus pada penjelasan yang disampaikan dosen. Hal ini antara lain karena lemahnya sikap ilmiah serta penguasaan konsep-konsep dasar fisika dan matematika ditambah lagi dengan keengganan mahasiswa untuk membaca artikel fisika pada media lain yang ada.

Untuk mengatasi permasalah diatas diperlukan suatu upaya sehingga mahasiswa tidak lagi menglami kesulitan dalam pemecahan masalah termodinamika. Upaya yang dikembangkan dalam hal ini adalah perlu peningkatan sikap ilmiah mahasiswa. Usaha yang dapat dilakukan adalah dengan menerapkan suatu metode pembelajaran yang dapat mengembangkan sikap ilmiah mahasiswa dalam pemecahan masalah dan memberikan peluang kepada mahasiswa untuk mengkonstruksi pengetahuannya sendiri dan menumbuh kembangkan pengetahuannya.

Model pembelajaran yang potensial dan efektif dalam mengembangkan domain tersebut adalah Model Pembelajaran Berbasis Proyek(Project Based Learning Model). Model tersebut mengacu pada filosofis konstruktivisme yaitu pengetahuan merupakan hasil konstruksi kognitif melalui suatu aktivitas siswa yang meliputi keterampilan maupun sikap ilmiah siswa sehingga dapat mengkonstruksi pengetahuannnya sendiri melalui pengalaman yang nyata (1). Model Pembelajaran Berbasis Proyek (Project Based Learning) adalah model pembelajaran yang menggunakan proyek

Penerapan Project Based Learning Model untuk Meningkatkan Sikap IImiah Mahasiswa dalam Rangka Menghadapi Era....

Andik Purwanto, Desy Hanisa Putri, Dedy Hamdani 
sebagai inti pembelajaran. Hanafiah dan Suhana mengemukakan bahwa Model pembelajaran ini merupakan model pembelajaran inovatif yang melibatkan kerja proyek dimana peserta didik bekerja secara mandiri dalam mengkonstruksi pembelajarannya dan mengkulminasikannya dalam produk nyata (2).

Menurut Dasna, tiga unsur penting dalam IPA diantaranya produk atau konten, proses atau metode, dan sikap. Kumpulan ilmu pengetahuan berupa konsep, teori, prinsip, atau hukum-hukum gejala alam merupakan produk dari IPA yang sering diwujudkan dalam bentuk teknologi. Proses IPA berkaitan dengan cara yang digunakan untuk memperoleh pengetahuan dengan sikap tertentu yang dikenal dengan sikap ilmiah (scientific attitude) yang merujuk pada perubahan tingkah laku yang diteliti , jujur, obyektif, berfikir rasional dan kritis. Sikap ilmiah tersebut sangat penting dalam kehidupan karena dapat membentuk pribadi manusia yang selalu menggunakan rasio dalam pertimbangan suatu keputusan. Sikap ilmiah pada dasarnya adalah sikap atau nilai-nilai yang muncul dari dalam diri yang mendorong seseorang untuk bertingkah laku terhadap suatu objek yang dilakukan secara sistematis melalui langkah-langkah ilmiah. Pengembangan sikap ilmiah mampu memberikan karakter bagi siswa sesuai dengan nilai-nilai ilmiah. Siswa yang memiliki nilai rasa keingintahuan yang tinggi, kritis terhadap suatu permasalahan, jujur, selalu mendahulukan bukti, kreatif, dan terbuka menunjukkan ciri siswa yang selalu berpikir dan bertindak secara ilmiah, terstruktur dan mandiri. Sikap-sikap tersebut sangat berpengaruh terhadap meningkatnya hasil belajar (3).

Salah satu upaya dalam pengembangan sikap ilmiah mahasiswa secara mandiri adalah memberikan kebebasan dalam proses pembelajaran. Konsep kebebasan pembelajaran ini sudah dimulai oleh Kementerian Pendidikan dan Kebudayaan dengan mengeluarkan program Kampus Merdeka Merdeka Belajar (MBKM). Program ini memberikan kebebasan kepada mahasiswa dalam menyelesaikan studinya sesuai dengan gaya masing -masing.

Terkait itu, kebijakan Merdeka Belajar-Kampus Merdeka sejalan dengan Peraturan Menteri Pendidikan dan Kebudayaan (Permendikbud) Nomor 3 Tahun 2020 tentang Standar Nasional Pendidikan Tinggi. Aturan itu dilaksanakan oleh sejumlah pihak yang terkait, antara lain, perguruan tinggi (PT), fakultas, program studi, mahasiswa, dan mitra. Bagi pengelola PT, wajib memfasilitasi hak bagi mahasiswa (dapat diambil atau tidak) untuk: (a) dapat mengambil SKS di luar perguruan tinggi paling lama 2 semester atau setara dengan 40 SKS dan (b) dapat mengambil SKS di program studi yang berbeda di perguruan tinggi yang sama sebanyak 1 semester atau setara dengan 20 sks. Bagi pihak fakultas, harus (a) menyiapkan fasilitasi daftar mata kuliah tingkat fakultas yang bisa diambil mahasiswa lintas prodi dan (b) menyiapkan dokumen kerja sama (MoU/SPK) dengan mitra yang relevan (4).

Berdasarkan latar belakang yang telah diuraikan di atas, maka masalah penelitian ini adalah : Bagaimanakah penerapan Project Based Learning Model dapat meningkatkan sikap ilmiah dan hasil belajar mahasiswa pada mata kuliah Termodinamika guna menghadapi era merdeka belajar? Adapun tujuan penelitian ini adalah untuk mendeskripsikan sikap ilmiah dan hasil belajar mahasiswa pada mata kuliah Termodinamika melalui penerapan Project Based Learning Model guna menghadapi era merdeka belajar.

\section{METODE PENELITIAN}

Penelitian ini merupakan penelitian tindakan kelas (Classroom Action Research). Penelitian tindakan kelas dapat didefinisikan sebagai suatu penelitian tindakan (action research) yang dilakukan guru yang sekaligus sebagai peneliti di kelasnya atau bersama-sama dengan orang lain dengan jalan merancang, melaksanakan dan merefleksikan tindakan secara kolaboratif dan partisipatif yang bertujuan untuk memperbaiki atau meningkatkan mutu (kualitas) proses pembelajaran di kelasnya melalui suatu tindakan (action) tertentu dalam suatu kelas (5). Setiap siklus pada penelitian ini terdiri dari 4 tahap, yaitu 1) tahap perencanaan (planing), 2) tahap pelaksanaan tindakan (acting), 3) tahap pengamatan (observating), 4) Tahap refleksi (reflection). Alur dalam penelitian ini dapat dilihat pada Gambar 1. 


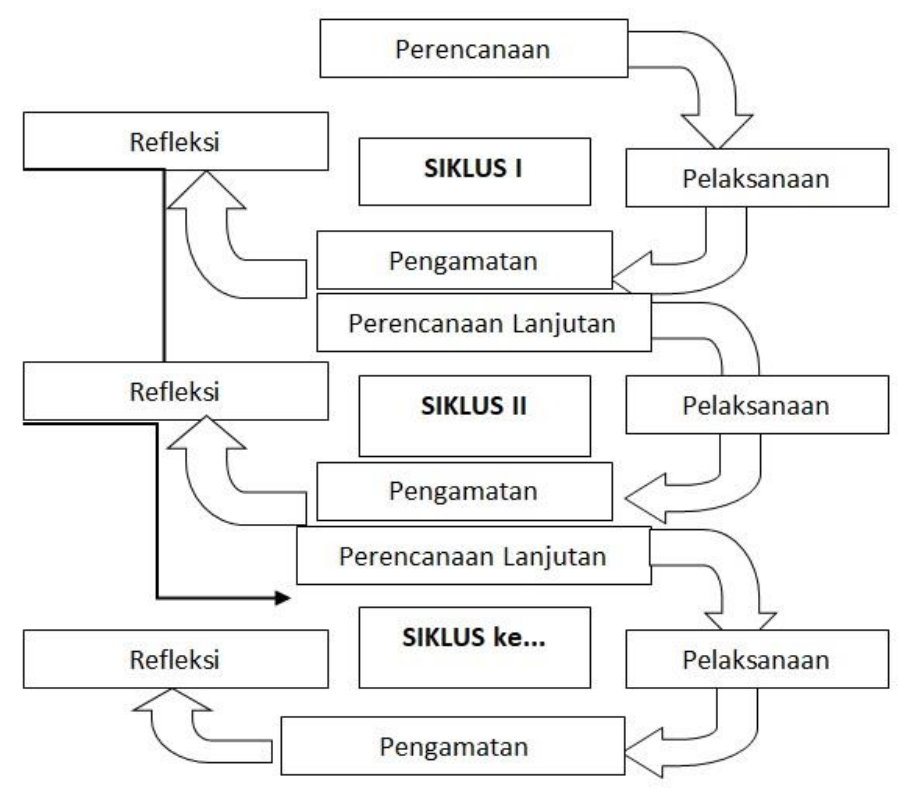

Gambar 1.Siklus kegiatan PTK (6)

Penelitian dilaksanakan pada mata kuliah Termodinamika yang telah dilaksanakan di https://www.elearning.unib.ac.id dan menggunakan zoom Universitas Bengkulu, dengan waktu pelaksanaan Juni s.d November 2020. Penelitian tidak dapat dilakukan secara tatap muka tetapi dalam mode jaringan dikarenakan adannya pandemi COVID-19. Populasi penelitian ini adalah mahasiswa program studi pendidikan fisika FKIP UNIB dengan sampel mahasiswa adalah mahasiswa pendidikan fisika semester 3 yang memperoleh mata kuliah Termodinamika.

Pengumpulan data diperoleh dengan menggunakan lembar angket sikap ilmiah mahasiswa dan tes hasil belajar aspek kogntif. Tes dilaksanakan pada akhir siklus. Sikap ilmiah yang dimaksud dalam penelitian adalah hasil dari tes sikap ilmiah yang berupa angket. Penyusunan item angket berdasarkan indikator yang telah ditetapkan sebelumnya. Responden atau siswa hanya dibenarkan menjawab pertanyaan dengan memilih salah satu alternatif jawaban yang telah disediakan. Skala pengukuran yang digunakan adala skala Likert yang mempunyai gradasi dari sangat positif sampai sangat negatif, yang dapat berupa kata-kata sangat setuju, setuju, ragu-ragu, tidak setuju, dan sangat tidak setuju. Skor tertinggi dari tiap butir adalah 5 dan yang terendah adalah 1 (7). Menurut Hadi, Skala Likert memiliki kelemahan yaitu pada kriteria ragu-ragu. Hal ini dikarenakan ada beberapa alasan. Misalnya, ragu-ragu memiliki arti ganda (netral). Selain itu, responden cenderung memilih jawaban tengah, terutama bagi mereka yang ragu-ragu kearah setuju atau tidak setuju. Maka dari skala Likert dimodifikasi menjadi empat skala penilaian (8).

Data angket dan tes dianalisis dengan menggunakan rata-rata nilai dan kriteria ketuntasan berdasarkan penilaian patokan menurut Panduan Buku Akademik Tahun 2020 Univeritas Bengkulu. Secara klasikal proses belajar mengajar dikatakan berhasil atau tuntas apabila mahasiswa di kelas memperoleh nilai $\geq C$ sebanyak $70 \%$. Secara individu siswa dikatakan berhasil jika memperoleh nilai minimum $\mathrm{C}$.

\section{HASIL DAN PEMBAHASAN}

\subsection{Deskripsi Hasil Penelitian}

\subsubsection{Deskripsi Hasil Pada Siklus I}

Pembelajaran siklus I dilakukan pada tanggal 16 September 2020. Tindakan yang dilakukan dalam siklus I ini adalah melaksanakan proses pembelajaran dengan menerapkan pendekatan Saintifik menggunakan model Project Based Learning menggunakan elearning.unib.ac.id dan berbantuan zoom meeting. Materi yang dipelajari pada siklus I ini merupakan konsep Hukum ke nol Termodinamika dengan sub konsep Temperatur dan pengukurannya.

\subsubsection{Hasil Sikap Ilmiah Siklus I}

Sikap ilmiah mahasiswa pada siklus I diukur dengan memberikan angket setelah mengikuti pembelajaran pendekatan saintifik dengan menggunakan model Project Based Learning. Angket Penerapan Project Based Learning Model untuk Meningkatkan Sikap Ilmiah Mahasiswa dalam Rangka Menghadapi Era....

Andik Purwanto, Desy Hanisa Putri, Dedy Hamdani 
berisi 20 pernyataan yang bersifat positif dan negatif. Adapun hasil penilaian sikap ilmiah siklus I dapat dilihat pada tabel 1.

Tabel 1. Hasil Sikap Ilmiah Mahasiswa Siklus I

\begin{tabular}{clccc}
\hline No & \multicolumn{1}{c}{ Aspek Sikap } & Jumlah butir & $\bar{X}$ & Kategori \\
\hline $\mathbf{1}$ & Rasa Ingin Tahu & 4 & 2,89 & Baik \\
$\mathbf{2}$ & Jujur & 2 & 2,51 & Cukup \\
$\mathbf{3}$ & Berpikir Kritis & 4 & 2,62 & Baik \\
$\mathbf{4}$ & Menemukan sesuatu yang baru & 3 & 2,71 & Cukup \\
$\mathbf{5}$ & Terbuka & 3 & 2,61 & Cukup \\
$\mathbf{6}$ & Bekerja sama & 3 & 2,78 & Baik \\
$\mathbf{7}$ & Ketekunan & 1 & 3,05 & Baik \\
& Kategori & & Baik & \\
\hline
\end{tabular}

Tabel 2. Persentase Sikap Ilmiah Mahaiswa Siklus I

\begin{tabular}{ccc}
\hline Kategori & Jumlah Siswa & Persentase (\%) \\
\hline Sangat Baik & 0 & 0 \\
Baik & 31 & 81,5 \\
Cukup & 7 & 18,5 \\
Kurang & 0 & 0 \\
\hline
\end{tabular}

Berdasarkan tabel 2 sebanyak 31 orang mahasiswa (81,5\%) masuk dalam kategori baik, 7 orang mahasiswa $(18,5 \%)$ masuk dalam kategori cukup dan tidak ada mahasiswa yang masuk dalam kategori kurang. Data ini menunjukan bahwa sikap ilmiah mahasiswa perlu ditingkatkan lagi. Namun jika dilihat skor sikap ilmiah per mahasiswanya maka masih ada siswa yang tergolong cukup, dapat dilihat bahwa masih ada mahasiswa yang tergolong kurang dalam bersikap ilmiah ketika melakukan proyeknya. Untuk aspek rasa ingin tahu dilihat mahasiswa masih ada tergolong kurang, karena pada proses pembelajaran masih ada mahasiswa yang kurang termotivasi dan tertarik terhadap proyek yang dilakukan. Begitu juga dengan menemukan sesuatu yang baru mahasiswa kurang kreatif dalam melakukan proyeknya hanya melakukan proyek berdasarkan prosedur yang diberikan, juga mahasiswa kurang menemukan hal-hal yang baru baik dari berbagai sumber. Untuk aspek terbuka mahasiswa sudah sangat baik dalam menerima pendapat, kritik dan saran pada saat diskusi dan presentasi.

\subsubsection{Deskripsi Hasil Belajar Siklus I}

Hasil belajar yang dimaksud dalam penelitian ini adalah hasil belajar pengetahuan mahasiswa berupa tes uraian soal. Hasil belajar siswa pada siklus I dapat dilihat pada tabel 3.

Tabel 3. Hasil Belajar Siklus I

\begin{tabular}{clc}
\hline No & Deskripsi Hasil Belajar Siswa & Nilai \\
\hline $\mathbf{1}$ & Skor terendah & 50 \\
$\mathbf{2}$ & Skor tertinggi & 85 \\
$\mathbf{3}$ & Jumlah mahasiswa yang tuntas & 7 \\
$\mathbf{4}$ & Daya Serap (\%) & $66,71 \%$ \\
$\mathbf{5}$ & Ketuntasan belajar Klasikal (\%) & $18,42 \%$ \\
\hline
\end{tabular}

Dari Tabel 3 merupakan hasil belajar mahasiswa siklus I, terlihat bahwa skor terendah adalah 50 dengan predikat D; skor tertinggi adalah 85 dengan predikat B dan jumlah siswa yang tuntas yaitu 7 orang. Dari data ini dapat dilihat bahwa sebanyak 31 mahasiswa yang belum tuntas (memperoleh skor < 76). Untuk skor rata-rata adalah 66,7 (D); daya serap mahasiswa sebesar $78,48 \%$ dengan ketuntasan belajar sebesar $18,42 \%$. Hal ini menunjukkan bahwa pembelajaran pada siklus I belum tuntas karena syarat ketuntasan belajar klasikal adalah $\geq 85 \%$ mahasiswa mendapat nilai $\geq 76$. Pembelajaran pada siklus ini belum maksimal disebabkan karena penerapan pendekatan Saintifik menggunakan model Project Based Learning belum sepenuhnya maksimal diterapkan.

\subsubsection{Refleksi Pembelajaran Siklus I}

Kegiatan refleksi pembelajaran perlu dilakukan untuk mendapatkan perbaikan pada siklus kedua. Beberapa kegiatan yang perlu diperbaiki adalah pada kegiatan pendahuluan sebaiknya dosen lebih memberikan contoh-contoh motivasi pembelajaran yang relevan dengan topik yang akan 
dipelajari, sehingga diharapkan mahasiswa menjadi lebih termotivasi dalam pembelajaran terutama mengerjakan proyek yang harus diselesaikannya. Kegiatan inti pembelajaran sebaiknya dosen lebih mengarahkan berbagai alternatif mencari sumber belajar dari proyek yang diberikan dari media elektronik maupun buku-buku pustaka. Kegiatan penutup pembelajaran sebaiknya dosen memberikan arahan untuk mahasiswa mempelajari sumber-sumber pembelajaran yang berkaitan dengan proyek.

\subsubsection{Deskripsi Hasil Siklus II}

Pembelajaran siklus II dilakukan pada tanggal 23 September 2020. Tindakan yang dilakukan dalam siklus II ini adalah melaksanakan proses pembelajaran dengan menerapkan pendekatan Saintifik menggunakan model Project Based Learning. Materi yang dipelajari pada siklus II ini merupakan konsep Persamaan Gas Ideal.

\subsubsection{Deskripsi Data Sikap Ilmiah Siklus II}

Sikap ilmiah mahasiswa pada siklus II diukur dengan memberikan angket kepada setelah mengikuti pembelajaran pendekatan Saintifik dengan menggunakan model Project Based Learning. Angket berisi 20 pernyataan yang bersifat positif dan negatif. Adapun hasil penilaian sikap ilmiah siklus II dapat dilihat pada tabel 4.

Tabel 4. Hasil Sikap Ilmiah Siklus II

\begin{tabular}{clccc}
\hline No & \multicolumn{1}{c}{ Aspek Sikap } & Jumlah butir & $\bar{X}$ & kategori \\
\hline $\mathbf{1}$ & Rasa Ingin Tahu & 4 & 2,99 & Baik \\
$\mathbf{2}$ & Jujur & 2 & 3,01 & Baik \\
$\mathbf{3}$ & Berpikir Kritis & 4 & 3,07 & Baik \\
$\mathbf{4}$ & Menemukan sesuatu yang baru & 3 & 3,25 & Baik \\
$\mathbf{5}$ & Terbuka & 3 & 3,39 & Baik \\
$\mathbf{6}$ & Bekerja sama & 3 & 3,41 & Baik \\
$\mathbf{7}$ & Ketekunan & 1 & 3,53 & Baik \\
$\quad$ Kategori & & Baik & \\
\hline
\end{tabular}

Tabel 5. Persentase Sikap Ilmiah Siswa Siklus II

\begin{tabular}{ccc}
\hline Kategori & Jumlah Siswa & Persentase (\%) \\
\hline Sangat Baik & 4 & 10,5 \\
Baik & 34 & 89,5 \\
Cukup & 0 & 0 \\
Kurang & 0 & 0 \\
\hline
\end{tabular}

Berdasarkan tabel 5 terjadi peningkatan jumlah mahasiswa yang masuk ke dalam kategori sangat baik pada siklus II yaitu sebanyak 4 orang mahasiswa $(10,5 \%)$, mahasiswa yang masuk kedalam kategori baik sebanyak 34 mahasiswa (89,5\%) sehingga terjadi peningkatan sikap ilmiah mahasiswa walaupun sedikit. Data ini menunjukan bahwa sikap ilmiah mahasiswa perlu ditingkatkan lagi. Pada siklus II ini mahasiswa belum optimal termotivasi dan tertarik terhadap proyek yang dilakukan. Begitu juga dengan menemukan sesuatu yang baru mahasiswa dianggap belum sepenuhnya kreatif, hanya melakukan proyek berdasarkan prosedur juga mahasiswa kurang menemukan hal-hal yang baru baik dari berbagai sumber. Untuk aspek terbuka mahasiswa sudah dianggap baik dalam menerima pendapat, kritik dan saran pada saat diskusi dan presentasi.

\subsubsection{Deskripsi Data Hasil Belajar Siklus II}

Hasil belajar aspek pengetahuan yang dimaksud dalam penelitian ini adalah hasil belajar pengetahuan mahasiswa berupa tes uraian. Hasil belajar mahasiswa pada siklus II dapat dilihat pada tabel 6.

Tabel 6. Hasil Belajar Siswa pada Siklus II

\begin{tabular}{clc}
\hline No & Deskripsi Hasil Belajar & Nilai \\
\hline $\mathbf{1}$ & Skor terendah & 60 \\
$\mathbf{2}$ & Skor tertinggi & 85 \\
$\mathbf{3}$ & Jumlah siswa yang tuntas & 20 \\
$\mathbf{4}$ & Daya Serap (\%) & 75,32 \\
$\mathbf{5}$ & Ketuntasan belajar Klasikal (\%) & 52,63 \\
\hline \multicolumn{2}{l}{ Dari Tabel 6 merupakan hasil belajar siklus II, terlihat bahwa skor terendah adalah 60 }
\end{tabular}

Penerapan Project Based Learning Model untuk Meningkatkan Sikap Ilmiah Mahasiswa dalam Rangka Menghadapi Era....

Andik Purwanto, Desy Hanisa Putri, Dedy Hamdani 
dengan predikat $\mathrm{D}$; skor tertinggi adalah 85 dengan predikat $\mathrm{B}$ dan belum semuanya tuntas yaitu 20 $(52,63 \%)$ orang. Daya serap mahasiswa sebesar 75,32\% dengan ketuntasan belajar sebesar 52,63\%. Data ini menunjukan bahwa secara klasikal proses pembelajaran yang menerapkan pendekatan Saintifik dengan menggunakan model Project Based Learning pada siklus II belum dapat dikatakan tuntas secara klasikal karena ketuntasan belajar secara klasikal tercapai apabila $\geq 85 \%$ dari jumlah mahasiswa memperoleh nilai $\geq 76$.

\subsubsection{Refleksi Hasil Sikus II}

Kegiatan refleksi pembelajaran perlu dilakukan untuk mendapatkan perbaikan pada siklus ketiga. Beberapa kegiatan yang perlu diperbaiki adalah (1) pada kegiatan pendahuluan sebaiknya dosen lebih memberikan contoh-contoh motivasi pembelajaran yang relevan dengan topik yang akan dipelajari, sehingga diharapkan mahasiswa menjadi lebih termotivasi dalam pembelajaran terutama mengerjakan proyek yang harus diselesaikannya. (2) Kegiatan inti pembelajaran sebaiknya dosen lebih mengarahkan berbagai alternatif mencari sumber belajar dari proyek yang diberikan dari media elektronik maupun buku-buku pustaka. (3) Kegiatan penutup pembelajaran sebaiknya dosen memberikan arahan untuk mahasiswa mempelajari sumber-sumber pembelajaran yang berkaitan dengan proyek.

\subsubsection{Deskripsi Hasil Siklus III}

Pembelajaran siklus III dilakukan pada tanggal 30 September 2020. Tindakan yang dilakukan dalam siklus III ini adalah melaksanakan proses pembelajaran dengan menerapkan pendekatan Saintifik menggunakan model Project Based Learning. Materi yang dipelajari pada siklus III ini merupakan konsep Persamaan Gas Lain.

\subsubsection{Deskripsi Data Sikap Ilmiah Siklus III}

Sikap ilmiah mahasiswa pada siklus III diukur dengan memberikan angket kepada setelah mengikuti pembelajaran pendekatan Saintifik dengan menggunakan model Project Based Learning. Angket berisi 20 pernyataan yang bersifat positif dan negatif. Adapun hasil penilaian sikap ilmiah siklus III dapat dilihat pada tabel 7.

Tabel 7. Hasil Sikap Ilmiah Siklus III

\begin{tabular}{clccc}
\hline No & \multicolumn{1}{c}{ Aspek Sikap } & Jumlah butir & $\bar{X}$ & Kategori \\
\hline $\mathbf{1}$ & Rasa Ingin Tahu & 4 & 3,32 & Sangat Baik \\
$\mathbf{2}$ & Jujur & 2 & 3,55 & Sangat Baik \\
$\mathbf{3}$ & Berpikir Kritis & 4 & 3,09 & Baik \\
$\mathbf{4}$ & Menemukan sesuatu yang baru & 3 & 3,76 & Sangat Baik \\
$\mathbf{5}$ & Terbuka & 3 & 3,54 & Sangat Baik \\
$\mathbf{6}$ & Bekerja sama & 3 & 3,46 & Baik \\
$\mathbf{7}$ & Ketekunan & 1 & 3,84 & Sangat Baik \\
& $\quad$ Kategori & & Sangat Baik & \\
\hline
\end{tabular}

Tabel 8. Persentase Sikap Ilmiah Siklus III

\begin{tabular}{ccc}
\hline Kategori & Jumlah Siswa & Persentase (\%) \\
\hline Sangat Baik & 33 & 86,8 \\
Baik & 5 & 13,2 \\
Cukup & 0 & 0 \\
Kurang & 0 & 0 \\
\hline
\end{tabular}

Berdasarkan tabel 8 terjadi peningkatan jumlah mahasiswa yang masuk ke dalam kategori sangat baik pada siklus III yaitu sebanyak 33 orang mahasiswa $(86,8 \%)$, sedangkan pada siklus sebelumnya belum ada mahasiswa yang dikategorikan sangat baik. Pada siklus III ini mahasiswa sudah mulai tertarik terhadap percobaan yang dilakukan. Begitu juga dengan menemukan sesuatu yang baru. Untuk aspek terbuka mahasiswa sudah baik dalam menerima pendapat, kritik dan saran pada saat diskusi dan presentasi.

\subsubsection{Deskripsi Data Hasil Belajar Siklus III}

Hasil belajar aspek pengetahuan yang dimaksud dalam penelitian ini adalah hasil belajar pengetahuan mahasiswa berupa tes uraian. Hasil belajar mahasiswa pada siklus III dapat dilihat pada tabel 9. 
Tabel 9. Hasil Belajar Siklus III

\begin{tabular}{clc}
\hline No & Deskripsi Hasil Belajar Siswa & Nilai \\
\hline $\mathbf{1}$ & Skor terendah & 70 \\
$\mathbf{2}$ & Skor tertinggi & 100 \\
$\mathbf{3}$ & Jumlah siswa yang tuntas & 33 \\
$\mathbf{4}$ & Daya Serap (\%) & 80,66 \\
$\mathbf{5}$ & Ketuntasan belajar Klasikal (\%) & 86,84 \\
\hline
\end{tabular}

Dari Tabel 9 merupakan hasil belajar mahasiswa siklus III, terlihat bahwa skor terendah adalah 70 dengan predikat B; skor tertinggi adalah 100 dengan predikat A dan belum semuanya tuntas yaitu 33 orang. Daya serap siswa sebesar 80,66\% dengan ketuntasan belajar sebesar 86,84\%. Data ini menunjukan bahwa secara klasikal proses pembelajaran yang menerapkan pendekatan Saintifik dengan menggunakan model Project Based Learning pada siklus III dapat dikatakan tuntas secara klasikal karena ketuntasan belajar secara klasikal tercapai apabila $\geq 85 \%$ dari jumlah mahasiswa memperoleh nilai $\geq 76$.

\subsection{Pembahasan}

Pada pembelajaran dengan menerapkan pendekatan Saintifik dengan menggunakan model Project Based Learning, dosen berperan sebagai fasilitator, motivator, mediator, inspirator, seniman pembelajaran dan desainer pembelajaran. Proses pembelajaran dengan menggunakan model Project Based Learning menuntut mahasiswa berperan aktif menemukan informasi sendiri dan mengkontruksi informasi tersebut dalam bentuk pengetahuan baru. Mahasiswa secara aktif menemukan konsep atau prinsip yang sebelumnya tidak dketahui melalui proses pengumpulan data (eksperimen). Proses 5M (mengamati, menanya, mencoba, mengasosiasi, menyimpulkan) dalam pendekatan Saintifik juga include kedalam proses pembelajaran. Pada pembelajaran dengan menggunakan model ini didapat bahwa sikap ilmiah dan hasil belajar siswa secara keseluruhan mengalami peningkatan tiap siklusnya.

\subsubsection{Sikap Ilmiah}

Sikap ilmiah merupakan gambaran mengenai bagaimana seharusnya siswa bersikap dalam belajar, menanggapi suatu permasalahan, malaksanakan tugas, dan mengembangkan diri yang pada akhirnya akan mempengaruhi hasil belajar siswa kearah yang positif (9). Sikap ilmiah sangatlah penting ditumbuhkan dan dikembangkan dalam pembelajaran IPA khususnya Fisika. Sikap ilmiah yang dilihat dalam penelitian ini ada 7 aspek yaitu sikap rasa ingin tahu, sikap jujur, sikap berpikir kritis, sikap menemukan sesuatu yang baru, sikap terbuka, sikap bekerjasama, dan sikap ketekunan. Ketujuh aspek ini diukur dengan memberikan angket yang berisi 20 pernyataan kepada siswa. Adapun hasil skor penilaian sikap ilmiah dapat dilihat pada tabel 10.

Tabel 10. Skor Rata-Rata Sikap Ilmiah

\begin{tabular}{cccccccc}
\hline \multirow{2}{*}{ Siklus } & \multicolumn{7}{c}{ Sikap Ilmiah } \\
\cline { 2 - 7 } & $\begin{array}{c}\text { Rasa Ingin } \\
\text { Tahu }\end{array}$ & Jujur & $\begin{array}{c}\text { Berpikir } \\
\text { Kritis }\end{array}$ & $\begin{array}{c}\text { Menemukan } \\
\text { Sesuatu yang } \\
\text { Baru }\end{array}$ & Terbuka & $\begin{array}{c}\text { Bekerja } \\
\text { sama }\end{array}$ & Ketekunan \\
\hline I & 2,89 & 2,51 & 2,62 & 2,71 & 2,61 & 2,78 & 3,05 \\
II & 2,99 & 3,01 & 3,07 & 3,25 & 3,39 & 3,41 & 3,53 \\
III & 3,55 & 3,55 & 3,09 & 3,76 & 3,54 & 3,46 & 3,84 \\
\hline
\end{tabular}

Sikap ilmiah secara keseluruhan sudah baik, artinya sikap ilmiah mahasiswa ketika melakukan proses ilmiah berupa proyek dalam pembelajaran sudah terlihat. Mahasiswa telah menunjukan bagaimana menjadi seorang peneliti dalam melakukan proyek. Hal ini telah sesuai dengan hakikat pembelajaran IPA, dimana dalam proses pembelajaran IPA terdapat proses ilmiah, produk ilmiah dan sikap ilmiah. Berdasarkan Tabel 10 terlihat bahwa sikap ilmiah mahasiswa meningkat dari siklus I hingga siklus III dengan menerapkan pendekatan saintifik dengan menggunakan model Project Based Learning. Hasil ini sesuai dengan penelitian Astawa, Sadya, Suastra pada 2019 (3). Peningkatan yang tidak terlalu tinggi dikarenakan untuk meningkatkan sikap ilmiah mahasiswa perlu proses pembelajaran yang berkesinambungan, intensif, secara terus- 
menerus dan memerlukan waktu yang lama untuk melihat perubahan dari sikap ilmiah seorang mahasiswa tersebut.

Pembentukan sikap seseorang dapat dilakukan dengan proses pola pembiasaan (coditioning) dan percontohan (modeling). Sikap ilmiah siswa ditumbuhkan dan dikembangkan lewat percobaan yang dilakukan siswa (10). Siswa dibimbing, diberi nasihat dan diberi contoh bagaimana melakukan penyelidikan sesuai dengan langkah-langkah ilmiah setiap siklusnya.

Aspek-aspek sikap ilmiah mahasiswa terdiri dari sikap rasa ingin tahu, sikap jujur, sikap berpikir kritis, sikap menemukan sesuatu yang baru, sikap terbuka, sikap bekerjasama, dan sikap ketekunan. Aspek rasa ingin tahu dan sikap menemukan sesuatu yang baru merupakan aspek dengan skor terendah dari setiap siklus namun masih tergolong dalam kategori baik. Aspek rasa ingin tahu mahasiswa mendapatkan kategori baik untuk setiap siklusnya. Namun aspek rasa ingin tahu mahasiswa merupakan sikap yang memiliki skor yang paling kecil dari pada aspek sikap ilmiah lainnya. Dalam proses pembelajaran mahasiswa sudah mulai mengembangkan rasa ingin tahunya lewat bertanya tentang pengamatan yang diberikan dosen, namun masih ada beberapa mahasiswa yang pasif dan memilih diam ketika diberikan fenomena-fenomena yang berkaitan dengan materi setiap siklusniya. Dosen juga sudah berusaha dalam memancing rasa ingin tahu mahasiswa dalam bentuk menyajikan materi dengan animasi yang lebih menarik lagi.

Aspek sikap ilmiah dalam berpikir kritis merupakan aspek yang memperoleh skor yang hampir konstant dalam setiap siklusnya. Hal ini menandakan sangat sulit bagi dosen dalam proses pembelajaran untuk meningkatkan sikap mahasiswa dalam berpikir kritis. Bagaimana mahasiswa teransang untuk memberikan kritikan, saran dan ide terhadap sesuatu dalam proses pembelajaran sangat perlu ditumbuhkan. Proses peningkatan dan manumbuhkan mahasiswa untuk bersikap berpikir kritis tidak mudah dilakukan. Perlu pembiasaan yang berkesinambungan dan waktu yang cukup lama dalam proses ini. Selain itu guru dituntut berpikir kreatif dalam menciptakan suasanasuasana yang dapat menmbuhkan sikap ilmiah ini. Tetapi secara keseluruhan aspek berpikir kritis mahasiswa dikategorikan sudah baik. Mahasiswa cenderung bertanya ketika ada hal yang keliru atau tidak dimengerti.

Aspek keterbukaan memperoleh skor yang baik setiap siklusnya. Sikap ini terlihat bagaimana mahasiswa menyikapi ketika terjadi perselisihan pendapat, menerima kritikan, saran dan berlapang dada ketika jawaban mereka salah pada saat presentasi.

\subsubsection{Hasil Belajar}

Adapun hasil belajar mahasiswa dalam mengikuti proses pembelajaran dengan menerapkan pendekatan saintifik dengan menggunakan model Project Based Learning yakni hasil belajar pengetahuan. Hasil belajar pengetahuan diukur dengan menggunakan tes soal setiap akhir siklus.

Tes soal berisi soal-soal yang telah divalidasi terlebih dahulu dan disusun berdasarkan indikator yang ada. Soal juga disusun berdasarkan tingkat Taksonomi Bloom aspek kognitif yaitu dipilih tingkat pemahaman (C2), Aplikasi (C3) dan tingkat Analisis (C4). Tes soal ini berfungsi untuk mengetahui kemampuan atau pemahaman konsep mahasiswa terhadap materi yang dipelajari setiap siklusnya. Ketiga siklus yang telah dilaksanakan ternyata terjadi peningkatan tes siklus mahasiswa pada aspek pemahaman konsep atau tes soal seperti diperlihatkan pada tabel 11 .

Tabel 11. Nilai Daya serap Tes Siklus Pengetahuan

\begin{tabular}{lcc}
\hline \multicolumn{1}{c}{ SIKLUS } & \multicolumn{2}{c}{ Nilai } \\
\cline { 2 - 3 } & Tes akhir siklus & Ketuntasan secara klasikal \\
\hline Siklus I & 66,71 & Belum tuntas \\
Siklus II & 75,32 & Belum tuntas \\
Siklus III & 80,66 & Tuntas \\
\hline
\end{tabular}

Peningkatan nilai tes siklus ini menggambarkan bagaimana peningkatan penguasaan mahasiswa terhadap materi pelajaran. Teori belajar kognitif menyatakan bahwa proses belajar yang dibangun oleh guru untuk mengembangkan kreativitas berpikir harus dapat meningkatkan kemampuan siswa dalam mengkontruksi pengetahuan baru sebagai upaya meningkatkan penguasaaan yang baik terhadap materi pelajaran (11). Peningkatan hasil belajar pada penelitian ini sejalan dengan penelitian mengenai pengaruh Model Pembelajaran Berbasis Proyek terhadap hasil 
belajar (1).

\section{SIMPULAN DAN SARAN}

4.1 Simpulan

Berdasarkan hasil penelitian dan pembahasan, diperoleh kesimpulan sebagai berikut: (1) Penerapan pendekatan saintifik menggunakan model Project Based Learning pada Matakuliah Termodinamika dapat meningkatkan sikap ilmiah mahasiswa semester 3 Prodi Pendidikan Fisika FKIP Universitas Bengkulu. (2) Penerapan pendekatan saintifik menggunakan model Project Based Learning pada matakuliah Termodinamika dapat meningkatkan hasil belajar mahasiswa Semester 3 Prodi Pendidikan Fisika Universitas Bengkulu. Untuk siklus I ketuntasan belajar pengetahuan $18,42 \%$ dengan daya serap 66,71. Kemudian siklus II dengan ketuntasan 52,63\% dengan daya serap 75,32. Pada siklus III dengan meningkat pada ketuntasan 86,84\% dengan daya serap 80,66.

\subsection{Saran}

Adapun saran perbaikan penelitian dimasa yang akan datang berupa: (1) Untuk meningkatkan variabel berupa sikap ilmiah, sebaiknya dilakukan dengan cara berkesinambungan dan membutuhkan waktu yang sedikit panjang agar mendapatkan hasil yang maksimal. (2) Untuk penelitian selanjutnya sebaiknya menggunakan teknik pengumpulan data yang lebih lengkap untuk meneliti sikap ilmiah.

\section{UCAPAN TERIMA KASIH}

Ucapan terima kasih kami berikan kepada Fakultas Keguruan dan Ilmu Pendidikan atas dana penelitian yang telah diberikan sehingga kami dapat menjalankan penelitian in.

\section{DAFTAR PUSTAKA}

1. Ferawati Wahida, Rahman N, Gonggo ST. Pengaruh Model Pembelajaran Berbasis Proyek Terhadap Keterampilan Berpikir Kreatif dan Hasil Belajar Siswa Kelas X SMA Negeri 1 Parigi. J Sains dan Teknol Tadulako. 2015;4(3):36-43.

2. Riadi M. Model Pembelajaran Berbasis Proyek (Project Based Learning/PjBL) [Internet]. KajianPustaka.com. 2017 [cited 2020 Apr 30]. p. 1. Available from: https://www.kajianpustaka.com/2017/08/model-pembelajaran-berbasis-proyek.html

3. Astawa IM, Sadya IW, Suastra IW. Pengaruh Model Pembelajaran Berbasis Proyek Terhadap Sikap Ilmiah dan Konsep Diri. J Pendidik DAN PEMBELAJARAN IPA Indones. 2015;5(2):1-11.

4. Sundaryanto, Widayati W, Amalia R. Konsep Merdeka Belajar-Kampus Merdeka dan Aplikasinya dalam Pendidikan Bahasa (dan Sastra) Indonesia. KODE J Bhs. 2020;9(2):7893.

5. Kunandar. Penelitian Tindakan Kelas. Jakarta: Rajawali Pers; 2011. 245 p.

6. Arikunto S. Prosedur Penelitian Pendektan Praktik. 15th ed. Jakarta: PT. Rineka Cipta; 2013. $173 \mathrm{p}$.

7. Sugiyono. Metode Penelitian Pendidikan. Bandung: Alfabeta; 2010.

8. Hartanto E. Perbedaan skala Likert Lima Skala dengan Modifikasi Skala Likert Empat Skala. Jakarta; 2012.

9. Martiningsih M, Situmorang RP, Hastuti SP. Hubungan Keterampilan Generik Sains dan Sikap Ilmiah Melalui Model Inkuiri Ditinjau Dari Domain Kognitif. J Pendidik Sains. 2018;6(1):24-33.

10. Sanjaya W. Strategi Pembelajaran Berorientasi Standar Proses Pendidikan. Jakarta: Kencana; 2006.

11. Abidin Y. Desain Sistem Pembelajaran dalam Konsteks Kurikulum 2013. Bandung: PT Refika Aditama; 2014. 